\title{
Fabricated Quotations as Cause for Libel Recovery by a Public Figure
}

\author{
Jeremy Feigelson $\dagger$
}

A public figure picks up a newspaper or magazine to read a story about himself. Within the story, between quotation marks, he finds words he never uttered. If the substance of the fabricated quotations is damaging, the public figure may feel that the publication has defamed him in a particularly damning way, by making the damage seem his own doing. How should a court respond when the public figure brings a libel action based on the fabrications?

In Masson $v$ New Yorker Magazine, Inc., ${ }^{1}$ a divided panel of the Ninth Circuit Court of Appeals affirmed summary judgment for the media defendants. For purposes of summary judgment, the court assumed that the defendants knew the damaging quotations they published-which purported to be verbatim-were very different (at least in language, and arguably in content) from the subject's actual words. Nonetheless, the majority endorsed the journalist's right to invent quoted material as long as the inventions "are either 'rational interpretations' of ambiguous remarks . . . or do not 'alter the substantive content' of unambiguous remarks."2 This ruling provoked an incredulous dissenting opinion, ${ }^{3}$ as well as critical commentaries by non-lawyers, ${ }^{4}$ accusing the majority of

† A.B. 1984, Princeton University; J.D. Candidate 1991, The University of Chicago.

1881 F2d 1452 (9th Cir 1989), reh en banc denied, 895 F2d 1535 (1990), cert granted, 111 S Ct 39 (1990). The Court will consider three questions: the extent to which the First Amendment protects publication of fabricated quotations; whether courts may resolve factual questions against public figure defamation plaintiffs in resolving summary judgment motions; and whether an "incremental harm" doctrine should immunize defendants against liability for defamatory fabricated quotations when the plaintiff's àctual statements were bombastic and provocative. See 59 USLW 3213 (Oct 2, 1990). This Comment focuses on the first question - that is, what substantive legal rule should control in a defamation case where plaintiff charges that fabricated quotations caused his injury.

2881 F2d at 1456, citing Dunn v Gannett New York Newspapers, Inc., 833 F2d 446, 452 (3d Cir 1987), and Hotchner $v$ Castillo-Puche, 551 F2d 910, 914 (2d Cir 1977).

381 F2d at 1464-86 (Kozinski dissenting). See also Case Comment, Masson v. New Yorker Magazine: Actual Malice and Direct Quotations-The Constitutional Right to Lie, 65 Notre Dame L Rev 564, 584-85 (1990) (endorsing Judge Kozinski's approach).

4 See, for example, James Warren, To Tell the Truth: Has the Court Given Journalists a Right to Lie?, Chicago Tribune 5:1 (Aug 30, 1989); Arthur Schlesinger, Jr., The Judges of History Rule, Wall St J AIO (Oct 26, 1989) (calling Masson a "blow against scholarship"). 
giving judicial approval to the worst type of journalistic or scholarly behavior. ${ }^{5}$

Other courts have developed varying approaches to fabricated quotations. Two cases, for example, seem to hold that the journalist who knowingly fabricates a quoted statement presumptively creates a triable issue of "actual malice"-that is, a jury question as to whether the journalist published a defamatory falsehood with knowledge or reckless disregard of its falsity, ${ }^{6}$ which is the required state of mind for a libel defendant under New York Times Co. $v$ Sullivan. ${ }^{7}$ Other opinions express more tolerance for fabricated quotations. $^{8}$

The Masson split evokes the competing schools of thought. The majority grants journalists wide latitude in their use of quoted material, in order to shield the press from the chilling effect of liability. The dissent calls for a narrower range of permissible uses of quoted material, to protect the media's subjects from the appearance of self-inflicted libel. This division parallels the essential tension in defamation law: how best to protect both press freedom and individual reputations, when protection of one interest often comes at the expense of the other.

This Comment will focus on three questions to analyze the appropriate standard of liability for fabricated quotations under the existing regime of constitutional defamation law. First, what constitutes a fabricated quotation? Second, when does a fabricated quotation constitute a "falsehood"? And third, what mental state is required to impose liability on the fabricator?

Section I of the Comment reviews the development of the actual malice rule in New York Times. Section II examines the case law on fabrication of quotations, illustrating both the broad range of journalistic conduct that one might reasonably term "fabrication" and the lower courts' doctrinal responses to such

- For a defense of Masson, see Andrew M. White and Peter C. Sheridan, In Defense of Poetic License: Why Created Quotations Deserve Constitutional Protection, Los Angeles Lawyer 28 (Apr 1990).

- Carson v Allied News Co., 529 F2d 206 (7th Cir 1976); and James v Gannett Co., Inc., 47 AD2d 437, 366 NYS2d 737 (1975), both discussed in more depth at notes 26 \& 34 and accompanying text.

7376 US 254 (1964). New York Times, discussed further at notes 10-18 and accompanying text, is the seminal case in modern libel law.

s Varnish $v$ Best Medium Publishing Co., 405 F2d 608, 612 (2d Cir 1968) (affirming jury instruction requiring finding of "substantial' falsity"); Dunn $v$ Gannett New York Newspapers, Inc., 833 F2d 446 (3d Cir 1987) (granting translators wide latitude to make potentially defamatory choices in use of quoted material). See notes $30 \& 38$ and accompanying text. 
conduct. Section III discusses how New York Times and its progeny, as well as the common law of defamation, help define the relevant falsehood in a fabrication case. Section IV suggests the appropriate mental state for liability in such a case. Finally, the Comment applies the test developed to the model cases outlined in Section II.

The Comment concludes that the courts should predicate liability on two factors. The fabricated quotation must create a defamatory difference-that is, an injury that precise quotation would not have caused. Second, liability should turn on the journalist's knowledge or reckless disregard of the defamatory impact of the fabrication, not just on knowledge that the quotation is fabricated. This proposed standard accords little weight to the mere act of abusing the quotation mark as a basis for imposing liability, thereby rejecting the strict approach of the Masson dissent. Both the common law and the Supreme Court's defamation jurisprudence mandate this leniency toward media defendants. ${ }^{9}$

\section{The Actual Malice Rule: New York Times and the Constitutionalization of Defamation LaW}

At common law, defamation was a strict liability tort. ${ }^{10}$ Publication of a falsehood causing reputational injury led to liability, regardless of the defendant's state of mind. New York Times added to the common law test the "actual malice" element-a scienter requirement for libel defendants. By imposing this requirement, the Court consciously tilted the scales in libel cases toward protection of media defendants despite the potential for uncompensated reputational injury. New York Times is the logical starting place to determine when a fabricated quotation demonstrates actual malice.

\footnotetext{
- This Comment deals only with those statements to which the New York Times standard of "actual malice" applies. Standards of defamation liability for the same journalistic conduct differ depending on whether the plaintiff is a public or private figure, and on whether the disputed publication relates to a matter of public or private concern. See Rodney A. Smolla, Law of Defamation $\$ 3.05$ at 18-19 (Clark Boardman, 1986), for a summary of the varying standards of fault. The courts have rigged this sliding scale so that public figures generally have a harder time winning libel suits. It is thought that public figures have volunteered for a certain amount of media abuse as the price of fame, and are more likely than private figures to have access to the press in order to correct falsehoods. See Gertz v Robert Welch, Inc., 418 US 323, 344-45 (1974).

${ }^{10}$ For background on defamation law, see W. Page Keeton, Dan B. Dobbs, Robert E. Keeton, and David G. Owen, eds, Prosser and Keeton on the Law of Torts $\S 111$ at 772-73 (West, 5th ed 1984).
} 
The Times printed an advertisement criticizing Montgomery, Alabama, authorities for harassing civil rights demonstrators. The plaintiff, a Montgomery official who alleged that the ad libeled him because it contained several inaccurate statements of fact, won a $\$ 500,000$ judgment at trial and the Alabama Supreme Court affirmed. ${ }^{11}$ The United States Supreme Court reversed, holding that a public official plaintiff must prove "actual malice"-that is, that the defendant published with knowledge or reckless disregard of the publication's falsity. ${ }^{12}$ Any lesser standard would chill the "uninhibited, robust, and wide-open" debate essential to discourse on public issues. ${ }^{13}$

The actual malice standard added a state of mind requirement to the plaintiff's prima facie case. As Justice Brennan wrote for the majority:

A defense for erroneous statements honestly made is no less essential here than was the requirement of proof of guilty knowledge which ... we [have] held indispensable to a valid conviction of a bookseller for possessing obscene writings for sale. . . A rule compelling the critic of official conduct to guarantee the truth of all his factual assertions-and to do so on pain of libel judgments virtually unlimited in amount-leads to a comparable "self-censorship."

Just a few months after deciding New York Times, the Court created a distinction crucial to the issue of fabricated quotations. While "erroneous statements honestly made" merit protection against libel judgments, the Court emphasized, "calculated falsehood" does not:

The use of calculated falsehood, however, would put a different cast on the constitutional question. ... For the use of the known lie as a tool is at once at odds with the premises of democratic government and with the orderly manner in which economic, social, or political change is to be effected. . . . Hence the knowingly false statement and the false statement made with reckless disregard of the truth, do not enjoy constitutional protection..$^{15}$

The Court has since extended the actual malice standard to govern virtually all cases in which the plaintiff is a public figure

\footnotetext{
1273 Ala 656, 144 S2d 25 (1962).

12376 US at $279-80$.

13 Id at 270 .

14 Id at 278-79.

${ }^{15}$ Garrison v Louisiana, 379 US 64, 75 (1964).
} 
and the issue treated by the allegedly defamatory publication is of public concern. ${ }^{16}$ While a private figure may generally recover upon a showing of negligence, which by definition implies violation of a predetermined standard of journalistic care, ${ }^{17}$ the public figure plaintiff must meet the higher threshold of actual malice. The Supreme Court has explicitly rejected the notion of a negligence or professional standards regime for public figure libel cases. ${ }^{18}$

New York Times and its progeny effectively carve out three categories of published statements of apparent fact. The first category-correct statements of fact-is always privileged. The second category includes false statements of apparent fact published without knowledge or reckless disregard of their falsity; these statements are constitutionally protected error. The freedom to publish such statements without fear of liability is part of the "breathing space"18 necessary to freedom of the press. The third category, unprotected error, includes false statements of apparent fact published with knowledge or reckless disregard of their falsity.

A fabricated quotation cannot be a literal statement of fact, so it belongs in either the second or the third category. The plaintiff must persuade the court to place a given fabrication in the third category by proving reputational injury, falsity, and actual malice (i.e., knowledge or reckless disregard of falsity). This Comment assumes the requisite injury, proof of which will depend entirely on the facts of a given case, and proceeds to address the remaining elements of falsity and mental state. ${ }^{20}$ The essential tasks, then, are to describe the journalistic behavior at issue, and to define falsity and mental state in the context of that behavior.

16 The term "public figure" includes government officials and "anyone who has arrived at a position where public attention is focused upon him as a person." Keeton, et al, Prosser and Keeton on the Law of Torts $\S 117$ at 859-60 (cited in note 10). See the chart of liability rules in Smolla, Law of Defamation $\S 3.05$ at $18-19$ (cited in note 9).

${ }^{17}$ Gertz, 418 US at 348-49 (states may permit private figures to recover actual damages if they can prove fault and punitive damages if they can prove actual malice).

${ }^{18}$ See, for example, Harte-Hanks Communications, Inc. $v$ Connaughton, $109 \mathrm{~S} \mathrm{Ct}$ 2678, 2684 (1989) ("a public figure plaintiff must prove more than an extreme departure from professional standards"); see also Curtis Publishing Co. $v$ Butts, 388 US 130, 155, 16263, 170, 172 (1967) (majority rejects standard based on highly unreasonable conduct and extreme departure from ordinary standards of investigation and reporting). (1963).

10 New York Times, 376 US at 271-72, quoting NAACP v Button, 371 US 415, 433

20 The legal definition of "actual malice" differs from its everyday meaning. Judge Pierre Leval chose to substitute the term "state of mind" in the Westmoreland litigation to avoid prejudice and confusion. Westmoreland v CBS Inc., 596 F Supp 1170, 1178 (S D NY 1984) (supplemental opinion). This Comment generally uses the same substitution. 


\section{Defining Fabrication: Examples and Lower Court RESPONSES}

Lower courts have confronted a range of journalistic behavior in cases of fabrication or alteration of quoted material. The following sub-sections summarize some model cases and hypothetical situations, each illustrating a different type of fabrication and a different problem for the courts, and discuss the doctrines applied to these fabrication cases by various appellate courts.

\section{A. Incidents of Fabrication}

1. Masson::21 fabrications that synthesize, recast, or embellish actual statements.

Jeffrey Masson, a controversial psychoanalytic scholar, gave lengthy interviews to the journalist Janet Malcolm about the debate his criticisms of Sigmund Freud stirred in the analytic community and about his termination as Projects Director of the Freud Archives. Malcolm used the interviews as the basis for two articles in the New Yorker. The articles contained many quotations from Masson but no indication that Malcolm had altered the quoted material.

Masson alleged that Malcolm fabricated several defamatory quotations. Malcolm claimed that Masson did utter the disputed statements but could produce no tape recordings to prove her point. For purposes of summary judgment, the trial and appellate courts assumed that Malcolm had indeed invented the quotations; this Comment will assume the same.

Some of Malcolm's fabrications could not possibly have damaged Masson. For example, Masson told Malcolm that he changed his middle name to Moussaieff because he "just liked it." Malcolm quoted Masson as saying that he changed his name because "it sounded better."'22 In other instances, however, Malcolm used statements by Masson as the raw material from which she fashioned new quotations that, Masson charged, went far beyond the meaning and impact of the originals. Here are three examples:

a) Masson said two board members of the Freud Archives considered him "a private asset but a public liability." Malcolm quoted Masson as saying that in the eyes of these board members,

${ }^{21}$ Masson v New Yorker Magazine, Inc., 881 F2d 1452 (9th Cir 1989).

${ }^{22}$ Id at 1456. 
"I was like an intellectual gigolo-you get your pleasure from him, but you don't take him out in public."23

b) Masson said Freud "didn't have the courage to stick with things that he knew were true." Malcolm quoted him as accusing Freud of "moral cowardice."24

c) Masson described how he would have enlivened Anna Freud's London home, had he been allowed to live there. But he said nothing quite as colorful as the published version: "[The house not only would have been] a place of scholarship, but it would also have been a place of sex, women, fun."2s

2. James: ${ }^{28}$ fabrications based on an actual interview, but with no analogous statements in support.

The plaintiff in James $v$ Gannett Co. was a belly dancer at the Encore Club in Rochester, New York. An article in the defendant's newspaper "suggested," as the court delicately put it, "that plaintiff had another source of income."27 At issue were two quotations. In the first, the reporter combined a paraphrase and a direct quotation: "[S] he admits to selling her time to lonely old men with money, for as much as $\$ 400$ per evening in one case "just to sit with him and be nice to him.' "228 In the second, the reporter quoted the plaintiff as saying, "This is my business. Men is my business."2o The plaintiff claimed that the reporter fabricated both quotations. The defendant did interview the plaintiff and in the process may have developed a belief that she was a prostitute. But the decision reports no evidence of actual statements closely resembling the published ones or of statements that would make the published quotations seem like a reasonable extrapolation from the plaintiff's actual words.

3. Dunn: ${ }^{\text {so }}$ fabrication through translation.

Concerned about litter in his city's streets, the mayor of Elizabeth, New Jersey said the problem stemmed partly from "new peo-

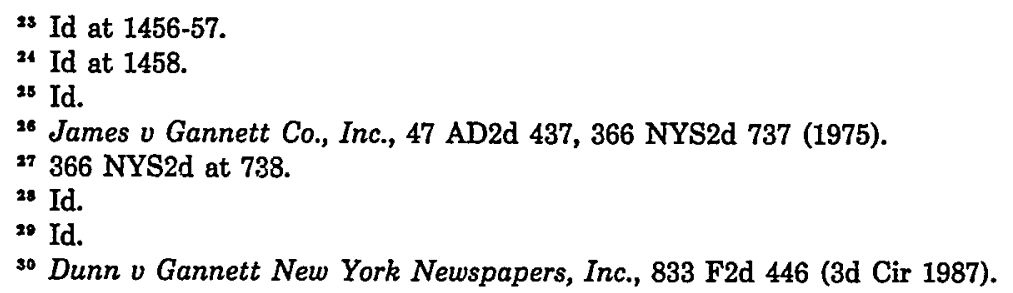


ple ... coming from foreign lands where abject poverty was something they lived with every day and [who] have not yet been assimilated into our type of society."31 A Spanish-language newspaper reported the mayor's comments under a headline that read, when translated, "Elizabeth Mayor on the attack: CALLS HISPANICS 'PIGS'."32 One of the newspaper's editors later explained that there were no exact Spanish equivalents for the words litter, litterbug, or litterpig. ${ }^{33}$ So the newspaper used the term "cerdos," the Spanish word for "pigs," and put it in quotation marks. Readers therefore got the impression that the mayor had, in fact, called his Hispanic constituents "pigs." nation.

4. Carson: ${ }^{34}$ fabrication entirely from the writer's imagi-

When Johnny Carson moved "The Tonight Show" from New York to Hollywood, a tabloid ran a story headlined, "Johnny Carson Is Moving 'Tonight Show' To Hollywood So He Could Be Closer To The Woman Who Broke Up His Marriage."ss Carson and "the woman," whom he later married, brought a libel action that centered on three inaccuracies. One of the three was an allegedly verbatim report of conversations between Carson and NBC executives in which Carson insisted that the network move the show to accommodate his love life. These were "wholly imagined but supposedly precisely quoted conversations." ${ }^{36}$ The reporter had no independent knowledge that such conversations had taken place, much less a transcript. The reporter testified that the fabricated conversations were "simply a logical extension" of the information he gleaned from another newspaper's story ${ }^{37}$ although that story did not refer to specific conversations between Carson and NBC executives.

5. Varnish: ${ }^{38}$ fabrication by selective quotation.

Joanne Varnish killed herself and her three children. In a note left for her husband Melvin, she said, "I can't go on any longer,"

si Id at 448.

${ }^{32}$ Id.

ss Id at $450-51$.

${ }^{34}$ Carson v Allied News Co., 529 F2d 206 (7th Cir 1976).

ss Id at 208.

se Id at 213.

s7 Id at 212.

ss Varnish v Best Medium Publishing Co., 405 F2d 608 (2d Cir 1968). 
explaining that depression and debt had driven her to suicide. ${ }^{39}$ The National Enquirer accurately reprinted a portion of the note. But it omitted the reference to depression and debt and quoted Joanne's husband, again with apparent accuracy, as saying, "I can't understand it. We had no troubles, no troubles at all. We were happy." ${ }^{\circ 0}$ The article also included a fictional quote attributed to "more than one neighbor" describing the Varnishes' perfect marriage. ${ }^{41}$ The selective quotation from the suicide note, in conjunction with the apparently accurate quotation from the distraught Melvin and the fabricated quote from the neighbors, created the impression that even after the tragedy Melvin thought his marriage had been perfect.

But Mr. Varnish had read the full suicide note, so he knew why his wife did what she did. In his suit against the Enquirer he argued, among other things, that the tabloid "portrayed him in a false and unsympathetic light by implying that he was lacking in sensitivity and understanding." $42 \mathrm{By}$ omitting key portions of the suicide note, he charged, the Enquirer had given the note a fundamentally different meaning.

\section{B. A Definition}

In each of the five cases outlined above, the quoted person felt injured by the fabrication, and sensationalism or ill will seems the most plausible explanation for the journalist's actions. But gratitude on the subject's part, accompanied by good faith and good will on the journalist's part, may just as plausibly characterize other sorts of fabrication.

The journalist faces a great temptation, perhaps even a necessity, to knowingly change or rearrange the speaker's words in a good faith effort to convey the speaker's point. ${ }^{43}$ One can sense just how inarticulate most speakers are by reading the unedited transcript of almost anything, even the remarks of the President of the United States. ${ }^{44}$ The journalist may also face a choice between

30 Id at 611-12.

40 Id at $610 \mathrm{n} 1$.

$\$ 1$ Id.

42 Id at 613 (Hays dissenting).

43 Suppose the journalist interviews a public figure, such as a scientist or diplomat, to whom fine points of language are important. She "translates" some technical jargon spoken during the interview into a "quotation" in plain English for the benefit of lay readers.

14 President Bush gave this answer to a Tennessee high school student who asked him whether the White House would look abroad for ideas to improve education: "Well, I'm going to kick that one right into the end zone of the Secretary of Education. But yes, we 
causing injury and confusion through hyperliteral quotation and "fabricating" to avoid such results. ${ }^{48}$ Finally, the journalist may omit quotation marks entirely, yet create the appearance of selfinflicted damage through paraphrase of an actual quotation. ${ }^{46}$

When one hears that a journalist has "fabricated" a quotation, one may assume that the journalist has transgressed ethical boundaries because of ill will toward the subject or disdain for accuracy. But these examples illustrate some everyday situations in which journalists may stretch the literal meaning of the quotation mark while trying to help both the subject and the reader. That a journalist has somehow tampered with quoted material, then, should not itself create a presumption of unethical, improper, or injurious conduct. The courts must craft a legal rule in this area with care, to avoid penalizing routine and desirable journalistic activity.

No existing case proposes a working definition of "fabrication"; the courts seem to operate on the assumption that they know fabrication when they see it. But a coherent legal rule requires a definition of the conduct it aims to cover. The cases and hypotheticals above share two features that point toward a definition for purposes of this Comment. First, in each the journalist has deliberately invented a quotation or substantially altered the subject's actual words. These are not incidents of accidental or negligent misquotation. And the journalist has offered the reader no clue that the quotation marks signal irony, fictional dialogue, or anything but verbatim transcription.

have all-he travels a good deal, goes abroad. We have a lot of people in the department that does that. We're having a big international-this is not as much education as dealing with the environment-a big international conference coming up. And we get it all the time-exchanges of ideas." Maureen Dowd, The Language Thing, NY Times Mag 32 (July $29,1990)$.

The marvelously pithy person-in-the-street "quotations" that appear daily on the editorial page of USA Today appear to benefit from an editor's touch. See, for example, the remarkably nuanced opinions on the hostage situation in Lebanon which appeared in the "Voices" section on March 9, 1990. Voices, USA Today A8 (Mar 9, 1990). Compare Abigail van Buren, Dear Abby, Chicago Tribune 5:6 (Apr 15, 1990) (before she prints a letter, "[o]ffensive language is laundered, errors in grammar are corrected and nonessential details are omitted to conserve space").

45 Suppose a public official utters a statement sprinkled with phrases like "uh," "um," and "you know." Publication of a numbingly accurate transcript would not constitute a defamation, since it would be true. But it would make the official seem unable to utter a simple sentence. Rather than injure the speaker and confuse the reader, the journalist "fabricates" by not reprinting the speaker's every false start and hesitant sound. Some people might applaud the journalist's choice; others might say he has lied to his readers by depriving them of evidence that their leaders cannot talk straight.

t8 See Schermerhorn v Rosenberg, 73 AD2d 276, 426 NYS2d 274 (1980) (affirming libel judgment based on defamatory headline readers could interpret as a direct quote from plaintiff). 
Second, one can plausibly argue that each published quotation bears a very different meaning or connotation from the speaker's actual words. Compare "private asset but public liability" to "intellectual gigolo"; "litterbug" to "pig"; "I can't go on" to "I can't go on [because I'm too depressed and in debt to continue]." In each case the published quotation twists not just words but meaning.

Here, then, is a definition of "fabrication" for present purposes: the journalist fabricates a quotation when she deliberately places within quotation marks words that materially alter the form or content of the speaker's actual words, without notifying the reader of this alteration. This definition encompasses all five model cases, from the extreme of pure invention (Carson) to the middle ground of invention based on actual statements (Masson) to the other extreme of fabrication by accurate yet selective quotation (Varnish). Routine efforts to clean up, rearrange or "translate" the subject's words may also fall within the scope of this definition.

\section{Lower Courts' Doctrinal Approaches to the Fabrication Problem}

The courts split into two general camps over liability for fabricated quotations. The lenient camp does not assign liability as long as the fabrications capture the gist of the matter reported. The strict camp considers the quotation mark a crucial guarantor of accuracy and truthfulness in reporting and therefore is more likely to see the deliberate fabrication of a quotation as a calculated falsehood creating a jury issue of actual malice. ${ }^{47}$

\footnotetext{
${ }^{47}$ The courts often frame issues of libel doctrine in terms of what constitutes a jury question. Courts must test summary judgment motions in libel cases by the same burden of proof they would apply at trial. Anderson v Liberty Lobby, 477 US 242, 252-56 (1986). The court must grant a defendant's summary judgment motion unless the court believes the plaintiff could prove actual malice by clear and convincing evidence, which is the standard of proof in libel actions. Id at 255-56.

Summary judgment is a powerful tool for media defendants. Even before Anderson, prominent judges argued that courts must act aggressively to protect the First Amendment against the retributive instincts of juries. See, for example, Ollman v Evans, 750 F2d 970, 997 (DC Cir 1984) (Bork concurring) (calling for "close judicial scrutiny to ensure that cases about types of speech and writing essential to a vigorous first amendment do not reach the jury"); Wasserman v Time, Inc., 424 F2d 920, 922 (DC Cir 1970) (Wright concurring) (asserting that "actual malice [is] a constitutional issue to be decided in the first instance by the trial judge" on summary judgment). It is thus unusually plaintiff-protective for a judge to carve out, as Judge Kozinski does in his Masson dissent, a class of cases which presumptively goes to the jury.
} 
1. The lenient approach.

a) The Masson rule. The Masson majority exemplifies the lenient approach. By twisting, rearranging, and inventing quotations, Masson charged, Malcolm made him appear foolish and egomaniacal. But the district court granted summary judgment for the defendants, ${ }^{48}$ and the Ninth Circuit affirmed. This is the Masson rule:

A factfinder may infer actual malice from a fabricated quotation when the language attributed to the plaintiff is wholly the product of the author's imagination. An author may, however, under certain circumstances, fictionalize quotations "to some extent." Malice will not be inferred from evidence that the quoted language does not contain the exact words used by the plaintiff provided that the fabricated quotations are either "rational interpretations" of ambiguous remarks made by the public figure, or do not "alter the substantive content" of unambiguous remarks actually made by the public figure. ${ }^{49}$

Some of the published statements, such as the one about Masson's changing his middle name, were not substantially different in form or content from the actual statements. The court ruled that such fabrications could not support a libel claim. Similarly, the court readily dismissed the claim based on the statement that Masson had accused Freud of "moral cowardice" when he actually accused him of lacking "courage."

In other situations the relationship between the actual and published words was more tenuous, but the court still refused to find the fabrications actionable because they seemed like "rational interpretations." For instance, the court cited Masson's boast that he had slept with over 1,000 women as supporting the quotation in which he promised that he would have enlivened the Freud home with "sex, women, fun." That Masson made the boast in a context completely unrelated to his plans for the Freud home did not affect the court's analysis. Similarly, in finding the "intellectual gigolo" fabrication non-actionable, despite Masson's comparatively tame language, the court noted that the tone of the published quo-

${ }^{48}$ Masson v New Yorker Magazine, Inc., 686 F Supp 1396 (N D Cal 1987), affd, 881 F2d 1452 (9th Cir 1989).

49 881 F2d at 1455-56 (citations omitted).

${ }^{50} \mathrm{Id}$ at 1458. 
tation was consistent with "the many provocative, bombastic statements indisputably made by Masson."

b) Basic elements of the lenient cases. The lenient approach has two central elements: increased defamatory impact or altered content and "rational interpretation."

Masson borrowed one of its key tests, the question of whether the fabrication "increase[d] the defamatory impact or alter[ed] the substantive content" of a quotation, from the Second Circuit, which applied this metric in Hotchner $v$ Castillo-Puche ${ }^{\mathbf{6 2}}$ and in Varnish, the suicide note case. "[M]inor inaccuracies and fictionalized dialogue will not alone defeat the privilege granted to truthful publications of public interest," said the Varnish court, requiring instead a finding of "substantial' falsity." The court found for the defamed husband:

[T] he jury was entitled to accept plaintiff's view that the article as a whole presented a substantially false and distorted picture of him and his relationship with his wife.

[If] the plaintiff was not entitled to recovery, there would be insufficient restraint on reckless, irresponsible, and untruthful journalism..$^{\text {s4 }}$

The Varnish dissent disagreed with the majority's application of the test, noting that Melvin had testified at trial that he did not know why Joanne killed herself. "If the omitted part of the suicide message had been included, the story would have been more accurate but it would not have reflected plaintiff in any better light." The full picture was undeniably unflattering to Melvin: as the Enquirer reported, he went bowling and left his wife with the children on the night of the tragedy..$^{56}$

Leaving aside for a moment the question of whether the majority correctly applied its own test in Varnish, ${ }^{57}$ the case illustrates a central element of the lenient approach also evident in

s1 Id.

s2 551 F2d 910, 914 (2d Cir 1977). In Hotchner, Ernest Hemingway uttered a vivid and profane insult about the plaintiff. The publisher rewrote it, printing instead the mild statement, "I don't trust him." Under the test later adopted by Masson, the court refused to find the change actionable, because the plaintiff's reputational injury would have been worse if the real quote had appeared in print.

ss 405 F2d at 612 .

s4 Id at 612-13.

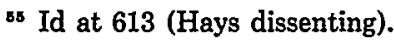

se Id at $610 \mathrm{n} 1$.

${ }^{37}$ Further discussion of this issue appears in text at note 115 . 
Masson and Hotchner: through misuse of the quotation mark, has the defendant created or exacerbated a defamation where precise quotation would have caused no injury or a lesser injury?

Another element of the lenient approach is the "rational interpretation" doctrine, applied in Masson and in Dunn, the translation case. ${ }^{58}$ The Masson majority used this doctrine to excuse certain fabrications that bore no resemblance to any actual quotations. For example, the court deemed the statement about bringing "sex, women, fun" to Freud's house a rational interpretation of Masson's unrelated statements about his sexual prowess.

In Dunn, the Third Circuit affirmed summary judgment for the Spanish-language newspaper because "the headline was a rational interpretation of remarks that bristled with ambiguities. . . [and] the word ['cerdos,' meaning 'pigs' in English,] was a fair, albeit inadequate, translation of the relatively new additions to the American vocabulary of the words 'litter,' 'litterer,' or 'litterbug'."'59 The court conceded the "inadequacy" of the choice, presumably conceding in some sense its "falsity" as well. But since translation is bound to be inexact, the court ruled, the plaintiff must present "countervailing factual evidence of actual malice," and Mayor Dunn had failed to do so. ${ }^{60}$ Presumably, Dunn would have had to prove that the newspaper chose the term "cerdos" with knowledge or reckless disregard of its inadequacy. Barring such proof, the newspaper's choice was false but fair.

The Dunn court ended its inquiry by assessing the "fairness" of the term "cerdos." By negative inference, then, the court said that to put a defamatory fabrication within quotation marks does not necessarily create a triable issue of actual malice. Dunn dealt with a foreign language translation, but the court did not limit its opinion to the translation context. Nor did it include any rhetoric about the sanctity of the quotation mark. One can easily imagine how with a little such commentary, the Dunn court could have reasoned to the opposite result. ${ }^{\text {B1 }}$

\footnotetext{
${ }^{68}$ Dunn and Masson borrowed the "rational interpretation" test from Time, Inc. $v$ Pape, 401 US 279 (1971). In that case the Supreme Court refused to find actual malice in Time magazine's decision to omit the word "alleged" from its description of an unproven incident of police brutality, largely because the government's own report on the incident was ambiguous on the question of the officer's guilt. The Court concluded that "Time's omission of the word 'alleged' amounted to the adoption of one of a number of possible rational interpretations of a document that bristled with ambiguities." Id at 290. Pape is discussed further in Section III.

838 F2d at 452 .

so Id.

62 The Masson majority cites Dunn for its "rational interpretation" theory. 881 F2d at
} 
2. The strict approach.

The strict approach depends heavily on judicial respect for the peculiar power of the quotation mark. When the speaker appears to defame himself, the reader has no reason to doubt his accuracy and the chance of reputational injury increases accordingly. In his Masson dissent, Judge Kozinski criticized the majority's use of a rational interpretation test:

[W]hen a writer uses quotation marks in reporting what someone else has said, she is representing that those are the speaker's own words or something very close to them.

..

What the court is saying, in effect, is that if you make statements that could reasonably be construed as boastful or arrogant (or callous or stupid or reflecting any other trait of character or intellect), the reporter may attribute to you any other statement reflecting that same trait. ${ }^{62}$

Judge Kozinski declared, in contrast, "that what somebody says is a fact, and that doctoring a quotation is no more protected by the first amendment than is any other falsification." ${ }^{63} \mathrm{He}$ then proposed a five-part test:

(1) Does the quoted material purport to be a verbatim repetition of what the speaker said? (2) If so, is it inaccurate? (3) If so, is the inaccuracy material? (4) If so, is the inaccuracy defamatory? (5) If so, is the inaccuracy a result of malice, i.e., is it a fabrication or was it committed in reckless disregard of the truth? ${ }^{64}$

The plaintiff would have to show that the answer to each question was "yes" to get to the jury. ${ }^{65}$ The first prong excludes satire. The second question excludes cases of genuine debate about the reporter's accuracy, such as a case where words on tape were inaudible and the court felt obliged to respect the journalist's judgment. The third excludes changes that "do not go to the substance" of the actual quotations, such as deletion of "uh"s and "um"s. The fourth element eliminates cases in which the published quotation

\footnotetext{
1456. Judge Kozinski's dissent suggests that Dunn should not apply "when everyone is speaking English." Id at 1471.

62 Id at 1464, 1466 (Kozinski dissenting).

as Id at 1478 (Kozinski dissenting).

os Id (Kozinski dissenting).

cs Id at 1478-79 (Kozinski dissenting). For further discussion of Judge Kozinski's test, see text at notes 74-76.
} 
causes no reputational injury. And the final prong protects journalists with no awareness of the differences between the actual and published statements.

The Seventh Circuit in Carson relied on a similar view of quotation marks in reversing the trial court's grant of summary judgment for the defendant:

In the catalogue of responsibilities of journalists, right next to plagiarism, . . . must be a canon that $a$ journalist does not invent quotations and attribute them to actual persons. If a writer can sit down in the quiet of his cubicle and create conversations as "a logical extension of what must have gone on" and dispense this as news, it is difficult to perceive what First Amendment protection such fiction can claim. ${ }^{66}$

The Masson majority interpreted this language as limited to cases in which the reporter invents quoted material without any factual basis for the invention and agreed that an inference of actual malice is justifiable in such a situation. ${ }^{67}$ But the Carson court itself suggested no such limitation, and the court's unequivocal language does not support the Masson majority's tolerance for fabrication with a reasonable basis.

A more coherent reading is that Carson and Masson represent a circuit split in all but name. The Seventh Circuit views invented quotations as presumptively creating a triable issue of actual malice, and the Ninth Circuit does not. As Judge Kozinski noted in his Masson dissent, under the Carson logic, Janet Malcolm's conduct is actionable. ${ }^{68}$ The difference between the two cases is that Malcolm did interview Masson, whereas Carson never spoke to the reporter he sued. But the Carson court's clear intolerance for fabrication seems to wash any meaning out of this distinction.

The strict view also controlled in James, the belly dancer case. The trial court deemed the plaintiff a public figure (with no apparent appreciation for the irony, given her profession) and granted summary judgment for Gannett. The appellate court reversed, holding that since the plaintiff categorically denied uttering the alleged fabrications, her denials created a triable issue of actual malice:

6 Carson, 529 F2d at 213 (emphasis added).

${ }^{67}$ Masson, 881 F2d at 1455-56.

os "If Carson does not cover a situation where the journalist invents a conversation that never took place and reports words that the subject never uttered, I am not sure exactly what it does cover." Id at 1472 (Kozinski dissenting). 
[I]f defendant's reporter fabricated the quotations, then defendant was guilty of actual malice in the constitutional sense because each quote was published "with knowledge that it was false or with reckless disregard of whether it was false or not." . . . The purpose of the New York Times rule is to promote the search for truth-not to encourage embellishment of the facts, and particularly not to encourage spicing-up a story with clearly libelous fabrications. ${ }^{68}$

Like Judge Kozinski and other adherents to the strict approach, ${ }^{70}$ this court seems to feel that a quotation is a fact, and a fabrication an actionable falsehood. It sees no reason to jump through hoops to protect a media defendant who might prefer a more nuanced definition.

3. The necessary inquiries: falsehood and state of mind.

The cases tend to avoid the essential tasks of defining falsehood and actual malice in this context. Judge Kozinski, for instance, simply declares that a fabricated quotation is a falsehood. $\mathrm{He}$ is obviously correct in a literal sense, but two inquiries remain necessary: What constitutes a falsehood for New York Times purposes? And precisely what sort of mental state should create culpability? To answer these questions, we need to examine both the progeny of New York Times and the common law of defamation. This dual inquiry will demonstrate that the mere act of deliberately printing a fabrication does not create a consequential falsehood; the plaintiff should have to prove a defamatory difference between the actual and published quotations in order to satisfy the common law element of injury. This inquiry will also demonstrate that the plaintiff should have to prove consciousness of the defamation, not just the fabrication, to satisfy the constitutional element of state of mind.

\footnotetext{
99 James, 366 NYS2d at 738-39 (citations omitted).

${ }^{30}$ For a state law case with a strict approach tracking Carson, see Selleck $v$ Globe International, Inc., 166 Cal App 3d 1123, 1132-33, 212 Cal Rptr 838 (1985) ("Falsely ascribing statements to a person which would have the same damaging effect as a defamatory statement about him is libel. ... [T] The article, including the headline and caption and taking into account the circumstances of its publication, is reasonably susceptible of a defamatory meaning on its face and therefore is libelous per se." (citations omitted)). See also Curran $v$ Philadelphia Newspapers, Inc., $497 \mathrm{~Pa} 163,439$ A2d 652, 661-63 (1981) (jury trial ordered where defendant made defamatory embellishments); Goldwater $v$ Ginzburg, 414 F2d 324, 337 (2d Cir 1969) (affirming libel judgment against defendant who "added certain innuendoes to some quoted statements and quoted other statements out of context in order to support his predetermined result").
} 


\section{Defining the Relevant Falsehood}

Defamation is a common law tort with three elements: publication, falsehood, and injury. Commentators rightly treat $\mathrm{New}$ York Times $v$ Sullivan as a landmark guarantor of constitutional freedoms. But New York Times has a more prosaic significance for the plaintiff assembling a defamation case: it simply adds state of mind as a fourth element of the tort. State of mind may be a constitutionally required element, but it is still just one element. And the court will not reach the state of mind issue unless the plaintiff can first prove the common law elements. This section initially discusses common law notions of falsehood and then considers how the Supreme Court's constitutional cases treat falsehood. A look at these two bodies of law leads to a single conclusion: falsehoods should have no legal consequence unless they injure in a way that literal truth does not.

\section{A. Defining "Falsehood": The Common Law of Defamation}

The common law of defamation supports a modified version of the lenient approach outlined above, one that embraces the substantial falsity element but rejects the rational interpretation element.

Although truth is traditionally the bedrock defense to a libel charge, "it is now generally agreed that it is not necessary to prove the literal truth of the accusation in every detail, and that it is sufficient to show that the imputation is substantially true, or, as it is often put, to justify the 'gist,' the 'sting,' or the 'substantial truth' of the defamation."71 The "gist or sting" principle applies neatly to the ambiguous situation of fabricated quotations: there is no good reason to let the plaintiff recover "if [the erroneous publication] produces the same effect on the mind of the recipient which the precise truth would have produced." Would the reasonable reader have thought just as poorly (or even more poorly) of the plaintiff if the defendant had quoted him with precision? If the 10).

71 Keeton, et al, Prosser and Keeton on the Law of Torts $\$ 116$ at 842 (cited in note

72 Williams $v$ WCAU-TV, 555 F Supp 198, 202 (E D Pa 1983). Accord, Elm Medical Laboratory, Inc. v RKO General, Inc, 403 Mass 779, 532 NE2d 675, 678 (1989); Reader's Digest Association, Inc. $v$ Superior Court, 37 Cal 3d 244, 690 P2d 610, 622 n 13 (1984) (" "A] defendant is not required in an action of libel to justify every word of the alleged defamatory matter; it is sufficient if the substance, the gist, the sting of the libelous charge be justified ... ." (quoting Kurata $v$ Los Angeles News Publishing Co., 4 Cal App 2d 224, 40 P2d 520, 522 (1935))). 
answer is yes, then the fabrication has created no defamatory difference. This difference moves the fabrication from the category of de minimis falsehood to the category of consequential falsehood-and thus into the realm of possible New York Times liability.

One could also say that the issue here is not the definition of falsehood, but the required nexus between falsehood and injury. A fabricated quotation is obviously a falsehood in a rudimentary sense. The question is whether the fabrication caused the injury. If the injury would have happened without the fabrication, the absence of a causal link makes the falsehood harmless. ${ }^{73}$

Arguably, Judge Kozinski's five-step test covers the same territory as the "gist or sting" test when he asks his third and fourth questions: "Is the inaccuracy material?" and "Is the inaccuracy defamatory?"74 The difficulty arises in reconciling these elements of Judge Kozinski's test with his stark statement that a quotation is a fact, which he contrasts with the majority's belief that a quotation is something "much more amorphous[]." Jus Judge Kozinski suggests that it is absurd to permit journalists to substitute merely similar words for precise quotations. When he creates exceptions to liability for two classes of deliberate fabrication, however, his analysis

\footnotetext{
73 A critique of Judge Leval's libel reform proposal reinforces the point that a fabricated quotation is not necessarily a falsehood. Leval suggests that courts ought to read New York Times as giving the plaintiff the choice of foregoing a claim for money damages. In exchange, the plaintiff could ask the court for a declaratory judgment on the truth or falsity of the publication, and the actual malice rule would not apply. Pierre N. Leval, The No-Money, No-Fault Libel Suit: Keeping Sullivan in its Proper Place, 101 Harv L Rev 1287 (1988). In theory, this approach would be as neat and elegant as the typical big libel suit is messy and indeterminate.

What result, however, if we funnel a fabrication case into this procedure? The plaintiff would say, "She made up words and put them in my mouth." The defendant, lacking tapes or transcripts that precisely match what she published, would say, "So I did." If a declaratory judgment for plaintiff follows, then we have settled on an overly literal definition of "falsehood" that seems to encompass every innocent misquotation, every good faith rearrangement of incoherent words, and every outright, mean-spirited fabrication. In order to avoid a sweeping expansion of the circle of liability, the common law "gist or sting" rule must apply in this context.

Suppose that for every fabricated quotation in Masson there really was a similar actual statement, and Malcolm's versions bore no greater defamatory impact than the originals. Then her actions did not cause plaintiff any distinct injury. A libel judgment allows the speaker to shift onto the journalist the blame for harm that really is self-inflicted. The fact that the journalist would pay no money damages lends little force to plaintiff's case. Since "[w] hatever is added to the field of libel is taken from the field of free debate," New York Times, 376 US at 272 , courts should hesitate to apply even Judge Leval's relatively inexpensive sanction to journalists.

"Masson, 881 F2d at 1478 (Kozinski dissenting).

7s Id at 1464 (Kozinski dissenting).
} 
becomes confused. Evidently, he and the majority agree that a journalist may tamper with or invent "facts" as long as they are 1) immaterial or 2) nondefamatory. Perhaps Judge Kozinski is backing into a "gist or sting" test for falsehood. More likely, he envisions a substantially broader class of actionable material that disregards the substantial accuracy defense. The latter is the more accurate interpretation, judging from the narrow nature of the examples he gives to illustrate these elements of his test. ${ }^{78}$

One can identify the relevant falsehood in a fabrication case, then, by asking a simple question. Does the journalist's fabrication create a defamatory difference? Hold actual statement A alongside published statement B. Suppose the words are different, even dramatically different, but the "gist or sting" is the same. There is a literal falsehood but no consequential falsehood. Only if the difference constitutes the defamation is there a consequential falsehood. This defamatory difference approach comports with the "substantial falsity" element of the lenient approach outlined above. The Court implicitly endorsed the substantial falsity doctrine in Hill, and the Second Circuit explicitly endorsed the doctrine in Hotchner and Varnish. ${ }^{77}$

Hersch $v E$ E.W. Scripps Co. ${ }^{78}$ provides further support for the "substantial falsity" element of the lenient approach. In Hersch, a judge chastised the plaintiff, a lawyer, for his "poor judgment" and "impropriety" in handling a case. The defendant newspaper reported instead that the judge accused the plaintiff of acting "stupidly." "79 The court labeled the fabrication a paraphrase, and found for the defendant:

[T]o paraphrase and print a derogatory statement made by another person is not defamatory unless the defendant employed words conveying "greater opprobrium" than the original language used.

${ }^{76}$ Id at 1480-81 (Kozinski dissenting). To take an example not offered by Judge Kozinski: suppose plaintiff tells defendant, "I behaved like a horse's ass." Concerned about publishing such graphic profanity, defendant prints instead the statement, "I behaved like a damned fool." This is a paradigmatic example of a case in which the substantial accuracy defense would defeat a libel claim. But Judge Kozinski would probably send it to the jury, because the change is material (the words are very different) and the fabrication is defamatory (never mind that the original is, too).

${ }^{77}$ Note Judge Hays' statement in the latter case: "If the omitted part of the suicide message had been included, the story would have been more accurate but it would not have reflected plaintiff in any better light." $405 \mathrm{~F} 2 \mathrm{~d}$ at 613 (Hays dissenting).

${ }^{28} 3$ Ohio App 3d 367, 445 NE2d 670, 680 (1981).

${ }^{78}$ Id at 676. 
[T]o be charged with having "acted stupidly" carries no greater opprobrium than to be charged with having committed an impropriety and with having exercised poor judgment. ${ }^{80}$

"No greater opprobrium" in this context has the same meaning as "gist or sting."

Given the common law endorsement of the substantial falsity element, what remains of the "rational interpretation" element that Masson and Dunn borrowed from Pape? ${ }^{81}$ The Pape court was not dealing with a case of fabricated quotation; the magazine did not purport to quote the government report at the point where it omitted "alleged." When applied to fabrication of direct quotations, however, the rational interpretation test may encourage farfetched literary analysis. Witness the Masson court's use of an actual quotation about the plaintiff's sexual prowess in support of a wholly unrelated fictional quotation that happened to mention sex. The rational interpretation test permits the court to adopt the journalist's subjective view of what constitutes the "gist or sting" of the original. ${ }^{82}$ In contrast, the defamatory difference approach forces the court to make a close and objective comparison between the published statement and the particular actual statement that it purports to represent.

Suppose that in Carson, an NBC executive told the journalist that he did have a testy conversation with Johnny Carson about moving the "Tonight Show" to California, but did not tell the journalist about any specific statements made during the meeting. Under the Masson court's construction, it might be a "rational interpretation" for the journalist to then invent quotations from the meeting that make Carson look hostile and contentious. But if no actual quotation supports what purports to be verbatim transcription, this construction seems odd, to say the least. Unlike Pape, this situation does not "bristle with ambiguities."83 Courts should limit the use of the "rational interpretation" approach to situations where there are such ambiguities. Wrongly interpreted, Pape could become a license to invent quotations from whole cloth.

so Id at $680-81$ (citation omitted).

81 See note 58.

82 The very use of the term "rational" signals that the court will give defendants the benefit of the doubt, just as rational basis scrutiny of legislation rarely results in a finding of unconstitutionality.

ss Pape, 401 US at 290. 
The requirement of close and objective comparison also distinguishes the defamatory difference approach from the "incremental harm" doctrine endorsed by the Ninth Circuit in Masson, which excuses fabrications that cause no injury distinct from that inflicted by the "nonactionable remainder of the publication." stead of measuring a published statement against an actual one for evidence of injury, the incremental harm approach measures the injury caused by the published statement against the injury caused by everything else in the article-a trickier and nearly metaphysical inquiry. This Comment does not attempt to analyze the incremental harm doctrine root and branch, but on brief consideration the doctrine seems inapplicable to fabricated quotations. It is hard to imagine what journalistic necessity or principle of public discourse excuses the reporter who "piles on" like an overeager linebacker, adding fabricated insult to actual injury.

\section{B. Defining "Falsehood": Supreme Court Case Law}

The Supreme Court has effectively endorsed a requirement of "substantial falsity" that meshes with the common law defense of substantial accuracy. The Court's cases suggest both significant tolerance for the abuse of journalistic discretion and utter intolerance for the knowing publication of untruths. When the Court tolerates such error and abuse at the expense of a plaintiff's reputation, it does so because it finds that liability would chill some significant aspect of public discourse. In New York Times itself, for example, the Court refused to find the newspaper liable for publishing an advertisement laden with errors, in part because the advertisement was clearly part of a public debate on an important civil rights issue. While the Court has never dealt with a case presenting facts like Masson's, existing decisions suggest approval of the common law "gist or sting" test of falsity. In constitutional terms, therefore, a fabricated quotation belongs in the second New York Times category, protected error, rather than the category of unprotected falsehood.

The Court has noted that journalistic discretion in selecting and interpreting quoted material is itself an element of public discourse worthy of protection. In Pape, the police brutality libel case cited by Dunn and Masson, a federal agency's report described an "alleged" act of police brutality. Time printed a version of the agency's account, but knowingly omitted the word "alleged." The

$8481 \mathrm{~F} 2 \mathrm{~d}$ at 1458. 
omission surely heightened the report's defamatory impact, because a reader could reasonably conclude that the federal government believed the plaintiff guilty of brutality. Still, the Court said,

Any departure from full direct quotation of the words of the source, with all its qualifying language, inevitably confronts the publisher with a set of choices.

Time's omission of the word "alleged" amounted to the adoption of one of a number of possible rational interpretations of a document that bristled with ambiguities. The deliberate choice of such an interpretation, though arguably reflecting a misconception, was not enough to create a jury issue of "malice" under New York Times. ${ }^{\mathrm{ss}}$

Pape indicates that departure from strict quotation is not presumptively actionable. But Pape did not deal with the knowing fabrication of facts or quotations. Classification of such fabrication as presumptively false and actionable remains a viable judicial course for lower courts. The Court has indicated elsewhere, however, that such fabrication is not necessarily the sort of "calculated falsehood"se that falls outside the scope of constitutionally protected speech under New York Times.

This is one of the lessons of Time, Inc. $v$ Hill, ${ }^{87}$ which concerned Life magazine's story on the play The Desperate Hours. Criminals had taken the Hill family hostage in their suburban home, and according to the article, the play dramatized this reallife experience. Life illustrated the story with photos specially staged in the Hills' home. In fact, the playwright based his work on many hostage incidents, not just the Hill incident, and the play differed in important respects from the Hill incident. ${ }^{88}$ The editor admitted knowing that the play was "between a little bit and moderately fictionalized," but insisted that he regarded the Hills' story as the "heart and soul" of the play. ${ }^{89}$

The Court set aside a jury award to the Hills because the trial judge had not offered an actual malice instruction. Notably, the Court did not quarrel with the New York Court of Appeals' con-

ss Pape, 401 US at 286, 290 (emphasis added).

so Garrison, 379 US at 75.

${ }^{87}$ Time, Inc. $v$ Hill, 385 US 374 (1967).

so The Hills' captors, for instance, had been courteous and nonviolent, unlike the vicious criminals depicted in the play and the article.

89 Id at 393. 
clusion in another case that a finding of "[m]aterial and substantial falsification" was necessary to support liability. ${ }^{90}$

Here we have what must seem to the layman a brazen lie. A national magazine prints pictures that purport to recreate a family's real experiences. But the magazine has good reason to believe that the pictures either depict incidents that never happened, or depict a cartoon-like distortion of reality. The courts did not begin, however, with the presumption that this intuitive notion of falsity controlled. Instead, they appeared to demarcate an area of material and substantial falsification from, presumably, an area of de minimis or non-actionable falsification that is within the scope of journalistic freedom protected by New York Times. As Justice Harlan wrote in his concurrence, "[I]n many areas which are at the center of public debate 'truth' is not a readily identifiable concept, and putting to the pre-existing prejudices of a jury the determination of what is 'true' may effectively institute a system of censorship." The "substantial falsity" approach is a core element of the lenient approach to fabrication. In Hill, the Court effectively endorses this element of the lenient approach. Applied in the First Amendment context, "substantial falsity" seems indistinguishable from the common law "gist or sting" test.

In other cases, the Court has made clear that the defendant earns no protection from libel judgments simply by disguising a known lie as a fact. The passage from Garrison $v$ Louisiana on "calculated falsehood," quoted above, is one example. ${ }^{92}$ In St. Amant $v$ Thompson, Justice White wrote:

[Defendant] cannot [] automatically insure a favorable verdict by testifying that he published with a belief that the statements were true. The finder of fact must determine whether the publication was indeed made in good faith. Professions of good faith will be unlikely to be persuasive, for example, where a story is fabricated by the defendant, is the product of his imagination, or is based wholly on an unverified anonymous telephone call. ${ }^{93}$

Cantrell v Forest City Publishing Co. provides one illustration of journalistic embellishment that did rise to the level of "calcu-

90 Id at 386 .

21 Id at 406 (Harlan concurring).

82379 US at 75; see text at note 15 .

${ }^{83} 390$ US 727, 732 (1968). 
lated falsehood."94 The defendant published a story about the grieving family of a man killed in a notorious bridge collapse. The story described the widow and paraphrased remarks she apparently made to the reporter. But the reporter neither met nor interviewed her in preparing the story. The Court upheld a jury verdict for the plaintiffs. ${ }^{95}$

The Supreme Court has not defined a harmonious doctrine on libel in general or on fabrication in particular. Perhaps the most accurate general statement one can make is that the Court is willing to protect some untruth when, as in New York Times or Pape, liability would deter people from engaging in some important form of public discourse. The Court recognizes a countervailing need to punish deliberate error, which, as Justice White notes in St. Amant, includes "fabrication" of a story. Cantrell displays similar intolerance of fabrication.

But Cantrell and St. Amant do not require that courts place all fabricated quotations in the category of unprotected error. Those cases criticize the wholesale invention of unsupported "facts." The invention or reconstruction of quoted material that bears some clear resemblance to the subject's actual words or meaning seems quite different. The deliberate fabrication of quotations may seem at first blush to serve no principle of public discourse. The definition of fabrication in this Comment, however, includes substantial alteration and selective quotation. Pure invention is only a subset of the behavior at issue. No reputable journalist would argue that he has a constitutional right to invent wholly unsubstantiated quotations. But the broader right to alter and select quoted material, and occasionally to print non-literal "quotations" that are substantively correct if not verbatim, is an important tool in the journalist's communicative arsenal. Mere "departure from full direct quotation ... with all its qualifying language," activity that we should hesitate to make the basis of a libel claim.

94 419 US 245 (1974).

28 Justice Stewart said:

[The reporter] must have known that a number of the statements in the feature story were untrue. In particular, his article plainly implied that Mrs. Cantrell had been present during his visit to her home and that [he] had observed her "wear[ing] the same mask of non-expression she wore [at her husband's] funeral." These were "calculated falsehoods," and the jury was plainly justified in finding that [the reporter] had portrayed the Cantrells in a false light through knowing or reckless untruth. Id at 253.

98 Pape, 401 US at 286. 
And with good reason. "[T]he public might be aghast if it knew how often reporters miscast or get [quotations] wrong (often unintentionally and benignly)." journalist the freedom to tamper somewhat with quotations, at the very least to straighten out grammatical or syntactic flaws in the subject's actual words so that the reader finishes the story more enlightened than confused. ${ }^{98}$ One imagines that both subject and reader often welcome and expect such fabrication. ${ }^{99}$ Public figures may be inarticulate. Readers nonetheless want to hear directly from them, for "without [their quoted] factual statements all news items would consist merely of the reporter's conclusions." 100 There is a tension between this need and the fact that so few speakers are truly articulate.

The exercise of this broader right to manipulate quoted material in good faith, including the right to print non-literal quotations, may sometimes be hard to distinguish from knowing, nasty invention. Courts should provisionally place a fabricated quotation in the protected error category rather than presume that it is a calculated falsehood, completely outside the First Amendment. Under the latter presumption, "lawsuits . . . could pose a threat to the ordinary, unobjectionable exercise of reportorial and editorial functions."101

\section{Defining the Relevant Mental State}

Under New York Times, the plaintiff must prove the defendant's knowledge or reckless disregard of the falsity of the publication. But what falsity must the defendant know or recklessly disregard? From the "gist or sting" test for falsity, we can derive the appropriate focus for the scienter element. The plaintiff must prove that the defendant knew or disregarded the defamatory difference between the defendant's actual and published statements.

97 Warren, To Tell the Truth at 5:1 (cited in note 4).

${ }^{98}$ Id at 5:2; see also Judge Kozinski's Masson dissent, 881 F2d at 1480.

9 See text at notes 43-46. Mayor Marion Barry of Washington, D.C., undoubtedly spoke for many public figures when he complained that a newspaper had tarnished his image by printing quotations in black dialect, "Most reporters realize that in casual conversation, grammar may occasionally slip; they account for this by making appropriate corrections in the written text. That is only fair." Marion Barry, Letter to the Editor, LA Times A14 (Jan 11, 1990) (emphasis added). If Barry's letter does express a common expectation among public figures, one wonders whether, as a matter of common sense and fairness, journalists rather than their subjects should "assume the risk" of fabrication.

100 James, 366 NYS2d at 744 (Cardamone dissenting).

${ }^{101}$ Robert D. Sack, Libel, Slander, and Related Problems 68 (PLI, 1980). Sack also notes that "[q]uotations are commonplace, the core of many news articles and published opinions." Id at 67. 
Judge Kozinski argues that simple knowledge of the act of fabrication should satisfy the New York Times mental state requirement. "Because I view quotations as facts, not opinion, I would ask a simple question: Did the defendants know that [the plaintiff's] actual statements differed from those attributed to him or did they act with reckless disregard with respect thereto?"'102 Kozinski's approach defines the relevant falsehood as the act of printing a fabrication, and the relevant mental state as knowledge or reckless disregard of the literal difference between the actual statement, A, and the published statement, B.

But as discussed above, the literal difference is not the legally relevant distinction. Section III defines the relevant falsehood as the degree of difference between the actual and the published statements. Therefore, the plaintiff should have to show that the journalist published with knowledge or reckless disregard of this degree of difference. The relevant falsehood is not the literal difference but the defamatory difference between $\mathrm{A}$ and $\mathrm{B}$. Therefore, the relevant mental state inquiry is: did the defendant know, or show reckless disregard for, the defamatory difference between $A$ and B? Liability thus hinges on consciousness of the defamation. Judge Kozinski skips a step; unless a defamatory difference exists, there is no common law defamation and inquiry into the defendant's state of mind becomes unnecessary.

Under this proposed approach the "good faith" fabricator, who creates an unwitting defamation in the course of altering quoted material to assist both subject and reader, will escape liability. This result follows naturally from the substantial accuracy standard: how can a journalist who adequately demonstrates a good faith belief in the substantial accuracy of his publication be said to have demonstrated "reckless disregard" for the truth? The concept of good faith as a defense to defamation did not originate in St. Amant. Defendants in common law libel actions, for instance, may exercise a qualified privilege of "fair comment," which "applie[s] if the publication complained of was a criticism or comment on a matter of public concern based on facts truly stated."103 The privilege predates New York Times. Historically, many courts have held that the plaintiff must demonstrate "reckless disregard

${ }^{102}$ Masson, 881 F2d at 1482 (Kozinski dissenting).

${ }^{103}$ Slade R. Metcalf, Rights and Liabilities of Publishers, Broadcasters and Reporters $\S 1.07$ at 21 (Shepard's/McGraw Hill, 1982). See also Ollman v Evans, 750 F2d 970, 974 n 5 (DC Cir 1984). 
of falsity, or lack of an honest belief in the statement or of good faith," to defeat the privilege. ${ }^{104}$ One should not be surprised that under the modern constitutional regime of libel law, good faith remains a defense. A good faith defense seems essential to protect the journalist who tampers with quoted material in an honest effort to serve both subject and reader.

The good faith fabricator pays damages under Judge Kozinski's test. The Kozinski regime might lead to more accurate quotations, but it might just as easily lead to an overall reduction in direct quotation and an increase in reportorial summarizing and paraphrasing. Such results would not necessarily promote truthful reporting.

Consciousness of the defamation is not ordinarily an element of liability under New York Times. One pair of commentators has argued that it should be required as a matter of course in public figure cases. ${ }^{108}$ They assert that New York Times does not permit recovery based on negligence, and if the plaintiff can show only that the defendant's statement was negligently defamatory, he has not met his burden of proof. The California Supreme Court seems to agree:

$[\mathrm{H}]$ onest belief of the defendant is the touchstone of the privilege enunciated in New York Times . . . . [T] ]he jury must find not only that the words were reasonably understood in their defamatory, factual sense, but also that the defendant either deliberately cast his statements in an equivocal fashion in the hope of insinuating a defamatory import to the reader, or that he knew or acted in reckless disregard of whether his words would be interpreted by the average reader as defamatory statements of fact. ${ }^{108}$

Moreover, one need not argue that an awareness-of-defamation requirement should apply in all libel suits to make a good ar-

\footnotetext{
${ }^{104}$ See Restatement (Second) of Torts $\$ 600$ at 87 (1977 \& 1981 Appendix) (citing English cases back to 1877 and American cases back to 1882).

108 "To ensure that liability is not imposed upon a faultless defendant, courts must require the plaintiff to establish with convincing clarity that the defendant was aware of, or blinded himself to, the allegedly defamatory meaning of the statement that he was making." Marc A. Franklin and Daniel J. Bussel, The Plaintiff's Burden in Defamation: Awareness and Falsity, $25 \mathrm{Wm} \&$ Mary L Rev 825, 836-37 (1984).

${ }^{108}$ Good Government Group of Seal Beach, Inc. v Superior Court, 22 Cal 3d 672, 684, 586 P2d 572, 578 (1978). See also Cochran v Indianapolis Newspapers, Inc., 175 Ind App 548, 372 NE2d 1211, 1219 (1978) (proof of intent to harm through falsehood is highly probative of actual malice); Tavoulareas v Piro, 759 F2d 90, 117 (DC Cir 1985) (common law malice is evidence of actual malice because it is evidence of motive to defame).
} 
gument that it should apply in fabrication cases. When the journalist simply invents "facts" out of whole cloth, for instance, it seems reasonable to say that he should assume the risk of injuring his subject. ${ }^{107}$ Similarly, when the journalist knowingly publishes a non-literal quotation that bears some close relation to the subject's actual words, his knowledge of the literal falsehood can be presumed. That assumption is merely a starting point. A literal falsehood does not always constitute a legally significant falsehood. ${ }^{108}$ Only a defamatory difference should make a literal falsehood actionable.

The mental state inquiry logically must focus on awareness of this difference. That the journalist consciously altered the subject's words proves only that the journalist has done what journalists do every day. One wants additional proof that he consciously or recklessly turned the screws, twisted the words, made the fabricated statement more harmful than its faithful transcription. ${ }^{109}$ Awareness of the relevant falsehood, the defamatory difference, and of the injury it causes necessarily coalesce. An awareness-of-defamation requirement in the fabrication context is entirely consistent with New York Times.

\section{The Test for Liability}

The above analysis dictates a two-step inquiry: First, does the difference between actual statement $A$ and published statement $B$ constitute the defamation? Second, did the defendant exhibit knowledge of or reckless disregard for the defamatory nature of the difference? The plaintiff must establish by clear and convincing evidence $^{110}$ an affirmative answer to both questions.

Two tasks remain: to step back from the piecemeal doctrinal analysis and determine whether the test comports with larger First Amendment principles, and to "test the test" by applying it to the cases discussed in Section II.

${ }^{107}$ Any injury resulting from the purely imaginary interview in Cantrell, for example, would fall into this category.

300 See Section III.

108 For example, "[a]lthough a reporter may have sufficient evidence of his charge to foreclose any material issue of constitutional malice for its publication, he may nonetheless make himself liable if he knowingly or recklessly misstates that evidence to make it seem more convincing or condemnatory than it is." Westmoreland $v$ CBS, Inc., 596 F Supp 1170, 1174 (S D NY 1984) (defendants allegedly left exculpatory material on the cutting room floor while broadcasting other material which tended to defame in the absence of the deleted footage).

110 See note 47. 


\section{A. Unprofessional Is Not the Same as Actionable}

This Comment largely rejects the strict approach. The journalist's need to clean up or rearrange sloppy language, and his license to synthesize, select, and "translate" in a good faith effort to serve the reader, are protected elements of public discourse under New York Times. But a simple and powerful argument remains to be addressed. Fabricated quotations are often examples of outrageous, unprofessional journalism: outrageous, because people understandably feel violated when a reporter tampers with their words, and unprofessional, because fabrications may be the tool of a journalist too lazy or spiteful either to get the quotation right or to signal the reader that he has altered, invented, or interpreted language. ${ }^{111}$ Citing numerous journalism experts, Judge Kozinski documents that as a matter of policy most journalists disapprove of fabrication. ${ }^{112}$

But the Supreme Court has sent an unmistakeable message through its rejection of a negligence standard for public figure libel cases: unprofessional journalism and actionable journalism are not identical. ${ }^{113}$ The journalism community may decry fabrication in a thousand policy statements. These protestations amount only to a proposed professional standard of care, deviation from which might constitute negligence. Yet negligence is not the law for public-figure libel. The actual malice standard intentionally immunizes good faith journalistic error from tort liability. The negligence approach would strip libel law of this constitutional protection.

Within the lousiness/outrageousness argument, however, there rests a subtler argument about the proper scope of First Amendment protections, sketched in crude fashion here. Justice Holmes's famous dictum, "the best test of truth is the power of the thought to get itself accepted in the competition of the market,"114 captures the time-honored notion that the First Amendment exists to pro-

111 It is easy to send such signals through brackets, ellipses, prefatory phrases such as "It was as if Smith had said," or a general disclaimer indicating that some material within quotation marks does not really purport to be verbatim. See Judge Kozinski's comments in Masson, 881 F2d at 1479 n 19.

112 Id at 1475-78 (Kozinski dissenting).

11 See Harte-Hanks Communications, Inc. v Connaughton, $109 \mathrm{~S} \mathrm{Ct} \mathrm{2678,} 2685$ (1989) (citing Curtis Publishing Co. v Butts, 388 US 130 (1967)).

11 Abrams v United States, 250 US 616, 630 (1919) (Holmes dissenting). In its discussion of "calculated falsehood" in Garrison, the Court endorsed to some extent this conception of the First Amendment as a structural protection for demacracy. Garrison $v$ Louisiana, 379 US 64, 75 (1964). Because New York Times and Garrison created the actual malice framework, it seems logical to adopt the marketplace conception for argument's sake. 
tect the search for truth. Truth and fact depend on one another because we reach the truth, arguably, by reviewing and assessing fact. It follows, in turn, that the law should create powerful incentives to promote accurate quotations and facts. Readers can then easily separate fact from opinion, and this fully informed citizenry can readily play its expected democratic role. The quotation mark is the "Good Housekeeping seal of approval" in the marketplace of ideas. Journalists who dilute its meaning diminish the First Amendment's guarantee of an open and effective market. A strict, pro-plaintiff standard for assessing fabricated quotations therefore promotes First Amendment principles more effectively than a lenient approach.

But the quotation mark does not belong on this pedestal. It offers scant protection against the influence of the reporter's opinions and value judgments. Chosen from among a mass of spoken words to illustrate the points the writer thinks most important, printed quotations typically comprise only a fragment of an article. Simply by selecting which quotations to print, the writer expresses opinions that shape the reader's thoughts and interfere with the ideal search for truth. Furthermore, rigid adherence to "fact" in this context does not necessarily serve "truth." Precise quotations reprinted wildly out of context provide one simple example of "facts" that may actually detract from truth.

Judge Kozinski correctly notes that the law should encourage journalists to quote people accurately. By holding journalists liable for a reckless or deliberate defamatory difference, the approach developed in this Comment provides ample incentives in that direction. This standard also comports fully with the First Amendment's command of maximizing press freedom by punishing only those journalists who have knowingly damaged their subjects.

\section{B. Applying the Test}

1. Does the difference constitute the defamation?

A plaintiff should not succeed in exploiting the mere fact of the fabrication if his wound really was self-inflicted. He must first show that, absent the fabrication, his reputation would not have been significantly injured and then establish the requisite mental state.

In Varnish, the case of the partially quoted suicide note, the dissent came closer to this standard because it focused on the sui- 
cide note itself. ${ }^{115}$ The majority appeared concerned with the cumulation of inaccuracies in the article which, though disturbing, were largely unrelated to the alleged defamation. The proper question is: Would readers have gotten the same essential impression of Melvin Varnish had the Enquirer printed the whole note, or substantially more of the note? The answer seems to be yes. Proper application of the "defamatory difference" principle leads to summary judgment for the defendant at this point in the test.

How would Masson work out under this part of the test? As Judge Kozinski correctly points out, a reasonable juror could conclude that Malcolm's embellishments and manipulations made the subject look foolish. Probably the best examples are "intellectual gigolo" and "sex, women, fun." Malcolm's fabrications made Masson look no more foolish than did his actual statements. Once we have discarded "rational interpretation" as a means of excusing quotations which bear no close relationship to actual statements, ample evidence remains to support a jury finding of defamatory difference-enough, in fact, to defeat defendant's summary judgment motion and send the plaintiff on to step two.

Dunn, Carson, and James go to step two as well. In Dunn, a clear defamatory difference exists between "pig" and "litterbug." In Carson and James there is no original, analogous quote, so if there is a defamation it necessarily stems from the fabrication. ${ }^{117}$

2. Did the journalist know or recklessly disregard the defamatory nature of the difference?

Having shown the objective fabrication-a significant, substantive, and defamatory difference between his actual words and his published quotations-a public-figure plaintiff must next establish the subjective element of mental state. He must prove the defendant's knowledge or reckless disregard of the fabrication's defamatory impact. Because the reported decisions largely ignore the question of mental state, they offer little evidence from which to predict the outcomes in the model cases.

115405 F2d at 613 (Hays dissenting).

$116881 \mathrm{~F} 2 \mathrm{~d}$ at 1467-69 (Kozinski dissenting).

${ }^{117}$ But see White and Sheridan, In Defense of Poetic License at 52 (cited in note 5) (fabrication without analogous quotations in support is permissible as long as "the author has solid background information from which the central meaning of the speaker's words can be logically and reasonably inferred. . .."). 
What would the plaintiff in each case have to prove by clear and convincing evidence? Jeffrey Masson would have to show that Janet Malcolm knew, or had reason to believe, that her embellishments would injure him in a way that his own words did not. Samantha James would have to show that the reporter knew, or had reason to believe, that the trumped-up admission of prostitution would cause reputational injury. Johnny Carson would have to show that the tabloid reporter knew, or had reason to believe, that the fabricated conversations would cause him reputational injury. Mayor Dunn would have to show that the author of the "cerdos" headline knew, or had reason to believe, that the substitution of "pig" for "litterbug" would cause reputational injury. Varnish would not reach this stage because the plaintiff would lose on the defamatory difference element.

The test proposed in this Comment, while lenient, is stricter than the Masson rule in one important way. By requiring a close comparison between actual and published statements, the proposed test discourages courts from embarking on fishing expeditions like those conducted by the Masson majority. Seemingly determined to rule for the defendant, the court combed the record for real quotations that made the fictional ones seem plausible. But Malcolm apparently did not argue that her inventions represented a good faith attempt to synthesize the material cited by the court. Under the proposed test, she loses on the question of defamatory difference because phrases like "intellectual gigolo" and "sex, women, fun" evoke a stark difference, in content and context, between the actual and published material.

Thus, Malcolm cannot use summary judgment to conceal her motivations. Under the proposed test she has to tell the plaintiff and the court what she thought she was doing-first in discovery, and then, if the judge finds that the plaintiff can prove actual malice at trial, to a jury. Summary judgment would remain available to protect Malcolm, and other defendants, against plaintiffs who fail to produce powerful pretrial evidence of actual malice.

The proposed test reflects the press-protective goals of $\mathrm{New}$ York Times. If the bad faith fabricator occasionally escapes liability under this test, that will be the price of protecting the actual malice regime. ${ }^{118}$ This test penalizes only the journalist who deliberately harms her subject, thereby satisfying the command of $\mathrm{New}$

118 "[I]t is essential that the First Amendment protect some erroneous publications as well as true ones." St. Amant $v$ Thompson, 390 US 727, 732 (1968). 
York Times: not to punish objective error, but, in crude terms, to sort out the good guys from the bad guys and punish only the bad.

\section{Conclusion}

The journalist fabricates a quotation when, without notifying the reader, she deliberately places within quotation marks words that materially alter the form or content of the speaker's actual words. While fabrication seems unappealing, this Comment defines it as encompassing the journalist's broad power to alter and manipulate quoted material in many ways. These exercises of journalistic discretion often benefit both subject and reader by clarifying inarticulate, garbled, or voluminous material.

When a public figure brings a libel suit based on a fabricated quotation, he must prove three elements under New York Times $v$ Sullivan: defamation, falsehood, and actual malice. Actual malice is defined as knowledge or reckless disregard of the publication's falsity. To prove defamation, the plaintiff must establish that the published quotation caused reputational injury. To prove falsehood, the plaintiff must establish that the defamation results from the fabrication per se. If the "gist or sting" of the published quotation is substantially true, the plaintiff has not proven falsehood. Rather, the difference between the actual and published statements must constitute the defamation. To prove actual malice, the plaintiff must prove consciousness of the defamatory difference between the actual and published statements.

Existing case law sketches two general approaches to the fabrication problem, one of leniency toward the fabricator and one of greater strictness. This Comment proposes a lenient test that leaves journalists substantial room to alter quoted material as long as they do not consciously or recklessly create a defamatory difference in the process. At the same time, the proposed test is more likely to create a jury question than the existing lenient approach. The proposed approach maintains the press protections of $\mathrm{New}$ York Times without giving journalists unbridled freedom to put words in their subjects' mouths. 